\title{
The importance of surveillance in children with minor head trauma: A case report
}

\section{Minör kafa travmalı çocuklarda gözlemin önemi: Olgu sunumu}

\author{
S. Kağan Başarslan' ${ }^{1}$, Arsal Acarbaş², Cüneyt Göçmez ${ }^{3}$
}

\begin{abstract}
Here we present an analysis of the case of delayed epidural hematoma which had a significant mass effect and required surgical evacuation. We consider that maintaining a high clinical suspicion, coupled with a low threshold for computed tomography scanning, is the key to morbidity prevention in this situation. Close observation for signs of clinical deterioration and repeat CT scan are the most important factors for early detection of the delayed epidural hematoma. J Clin Exp Invest 2014; 5 (1): 118-120
\end{abstract}

Key words: Children, epidural hematoma, head injury

\section{INTRODUCTION}

Delayed epidural hematoma (dEDH) can be described as the initial computed tomography (CT) scan is normal and subsequent CT scan shows a significant epidural hematoma (EDH) after trauma. The dEDH is rare, but only can be detected by the repeat CT scanning.

A minor head trauma is a very common condition in daily neurosurgical practice. It can be defined as an injury caused by blunt trauma or sudden acceleration or deceleration which produces a period of unconsciousness for 20 minutes or less, a Glasgow coma scale score of $13-15$, no focal neurological deficit, no intracranial complications and computed tomographic findings limited to a skull fracture without evidence of contusion or hematoma. Generally, many of physicians tend to early discharge these patients from hospital by favor of the patient's family comfort or insufficient hospital's facilities. However, especially in the pediatric population, such as minor entity may lead to dramatic consequences. In this report, we aimed to highlight one of the serious con-

\section{ÖZET}

$\mathrm{Bu}$ yazıda belirgin bası etkisi oluşturan ve acil cerrahi gerektiren geç epidural hematom olgusunun analizi sunulmaktadır. Böyle bir durumun oluşturacağı zararlardan korunmada klinik şüphe ile daha sık ve kolay bilgisayarlı tomografi incelemesinin anahtar rol oynadığını düşünüyoruz. Geç epidural hematomlar da klinik gerilemenin yakın takibi ile tekrar bilgisayarlı tomografi çekilmesi olguların erken saptanmasında en önemli faktördür.

Anahtar kelimeler: Çocuk, kafa travması, epidural hematom

sequences of such a risky situations seeming to be insignificant in the setting of trauma.

\section{CASE REPORT}

A 6-year-old boy was admitted with a history of fall from a couch. On neurological examination, he was fully conscious, oriented and cooperated with GCS as 15 point. The initial cranial CT scan was interpreted as normal. By inspection, it was also not disclosed any presence of trauma sign on the scalp such as ecchymosis, abrasion and edema or induration. The patient was discharged soon after with a prescription including analgesic, and certain recommendation his family to be alert for 24 hours. After only one and a half hour, he was brought to the emergency department again with unconscious status. A large epidural hematoma was appeared on the second cranial CT (Figure 1A), which was done at only 3 hours after his first admission. Then, he was taken to operation room, and hematoma was excavated by the surgical intervention immediately (Figure 1B).

\footnotetext{
${ }^{1}$ Department of Neurosurgery, School of Medicine, Mustafa Kemal University, Hatay, Turkey

${ }^{2}$ Clinic of Neurosurgery, State Hospital, Bolu, Turkey

${ }^{3}$ Department of Neurosurgery, School of Medicine, Dicle University, Diyarbakır, Turkey
}

Correspondence: S.Kağan Başarslan,

Department of Neurosurgery, School of Medicine, Mustafa Kemal University, Hatay, Turkey Email: kaganbasarslan@hotmail.com 


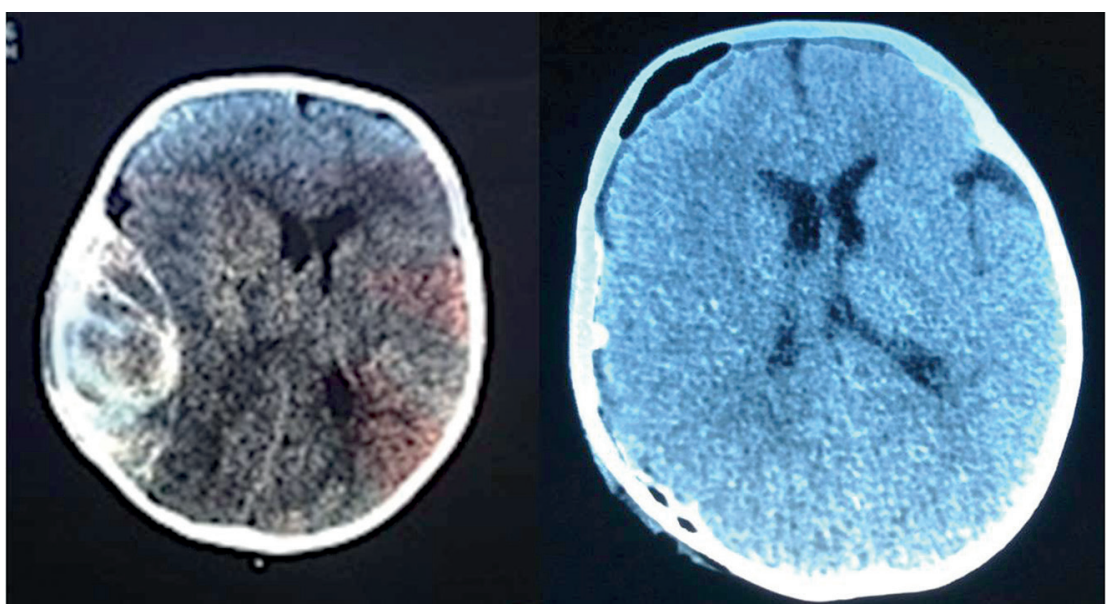

Figure 1. A) Pre and B) post-op brain CT of 6-year-old boy showing a large EDH and after his urgent operation.

With confirming of the first tomography appearance, an important detail being observed during the operation were that the bone overlying the hematoma was intact or no fracture possibly to cause this circumstances was detected. This suggests especially in children that the skull is maintained its shape by the elastically constitution like a flexible ball in pediatric population when curved concavely inward during collision. This may cause epidural bleeding without bone fracture.

\section{DISCUSSION}

A case of minor brain injury is an occurrence of injury to the head resulting from blunt trauma or acceleration or deceleration forces with one or more of the conditions as well as unconsciousness for 20 minutes or less, no focal neurological deficit or no intracranial complications, attributable to the head injury during the surveillance period [1]. The term "minor" is used in reference to the severity of the initial physical trauma that caused the injury. It does not indicate the severity of the consequences of the injury. So, the term "minor brain injury" can be misleading as in this case.

EDHs remain at the vertex of neurosurgical emergencies, representing approximately $3 \%$ to $8 \%$ of all serious head injuries. Mortality from this entity is usually prevented once the diagnosis is clear. Although readily recognized on plain head $\mathrm{CT}$, the occasional patient may go on to develop a clinically significant hematoma after an initial negative $\mathrm{CT}$. This phenomenon is appropriately termed as a $\mathrm{dEDH}$, and is considered to be uncommon, even in some large series is not mentioned at all $[2,3]$. Nevertheless, the incidence of dEDH has been reported to be $8-10 \%$ in all EDHs [4]. The dEDH can be diagnosed only by scanning the patient twice.
Otherwise it would be impossible to realize this lifethreatening entity.

The fundamental causes of traumatic dEDH are not only the source of bleeding or the separation of the Dura mater from inner surface of calvaria, as was shown in acute experimental models by Ford and McLaurin [4], but also include the disturbance of the equilibrium in the brain and the hemostatic effect of the intracranial pressure. Low intracranial pressure, high brain perfusion or rapid correction of hypotension acting concurrently or in isolation favor the production of a dEDH, especially at areas already injured $[5,6]$. In this case, one of these reasons can be means of the development of dEDH without skull fracture.

To emphasize the importance of follow-up of traumatic lesions by a CT, Durham et al. presented a retrospective study including 268 patients. In this study involving patients under the age of 18,54 patients $(20.1 \%)$ revealed no pathology on the control CT made within 24 hours after initial CT scan, but $61(28.5 \%)$ of these displayed radiological deterioration on their $\mathrm{CT}$. Based on these findings, they emphasized the importance of repetitive CT examination especially on patients with high-risk trauma [7]. With this case presentation, we are also emphasized that the sufficient observation and repetitive CT scan should be done in patients with the minor head trauma that have a potential to create the catastrophic results.

Kutlay et al. 7 cases of their dEDHs together with 48 cases reported in the literature was investigated. As a result of their examination they declared that these hematomas was emerged between 3th hours and 6th days after trauma and the most common localization was the frontal region [8]. Similarly in the case, dEDH is developed around 3 hours after head injury. 
We present a case of a 6-year-old boy developed a large epidural hematoma who had no clinical and radiological evidence till the second CT examination in a few hours after the injury. We feel that maintaining a high clinical suspicion, coupled with a low threshold for CT scanning, is the key to prevent from morbidity in this illness. A case considered as minor head trauma may lead to dramatic results if not paid attention adequately. The dEDHs are highly unpredictable and continue to cause diagnostic difficulty. Close observation for signs of clinical deterioration and repeat CT scan are the most important factors for early detection of dEDH. Early diagnosis and prompt operation offers excellent results.

\section{REFERENCES}

1. Alappat JP, Baiju, Praveen, et al. Delayed extradural hematoma: A case report. Neurol India. 2002;50:313315.
2. Giannotta SL, Weiss MH. Pitfalls in the diagnosis of head injury. Clin Neurosurg 1982;29:288-299.

3. Roberson FC, Kishore PRS, Miller JD, et al. The value of serial computerized tomography in the management of severe head injury. Surg Neurol 1979;12:161167.

4. Ford LE, McLaurin RL. Mechanisms of extradural hematomas. J Neurosurg 1963;20:760-769.

5. Bullock R, Van Dellen JR. Chronic extradural hematoma. Surg Neurol 1982;18:300-302.

6. Piepmeier JM, Wagner FC Jr. Delayed post-traumatic extracerebral hematomas. J Trauma 1982;22:455460.

7. Durham SR, Liu KC, Selden NR. Utility of serial computed tomography imaging in pediatric patients with head trauma. J Neurosurg 2006;105:365-369.

8. Kutlay M, Çolak A, Kıbıcı K ve ark. Travmatik gecikmiş epidural hematomlar: 7 yeni olgu ve literaturede rapor edilmiş 48 olgunun retrospektif analizi. Ulusal Travma ve Acil Dergisi 1998;4:273-280. 